\title{
Profitability and Technical Efficiency of Soybean Producers in the Municipality of Tanguiéta in Benin
}

\author{
Roger Chabi Bambani ${ }^{1}$, Pocoun Damè Kombienou ${ }^{2}$ \& Jacob Afouda Yabi ${ }^{1}$ \\ ${ }^{1}$ Doctoral School of Agronomic and Water Sciences (DSAWS) of the University of Parakou, Parakou \\ ${ }^{2}$ National Institute of Agricultural Research of Benin (NIARB), Laboratory of Soil, Water and Environmental \\ Sciences (LSWES), Republic of Benin \\ Correspondence: Pocoun Damè Kombienou, National Institute of Agricultural Research of Benin (NIARB), \\ Laboratory of Soil, Water and Environmental Sciences (LSWES), Republic of Benin. Tel: 229-9735-5649/9545- \\ 4959 .
}

Received: March 8, 2021 Accepted: May 6, 2021 Online Published: May 7, 2021

The research is financed by the own funds of the four_Researchers (Authors).

\begin{abstract}
This study was carried out in the year November 2020. The general objective of this study was to assess the profitability and Technical efficiency of soybean producers in the municipality of Tanguiéta. A survey of a sample of 184 producers was selected at random in Center of Tanguiéta, Taïacou, Cotiakou, N'Dahonta and Tanongou of the municipality. In order to analyze the financial profitability of soybean production, the interviews focused on data in order to estimate the technical efficiency scores of each producer and to establish the operating account of the sampled producers. Thus, the most efficient and the average or weakly efficient producers whose technical efficiency scores are less than or equal to $50 \%$. Gross margin, yield, value added per hectare and profit to production cost ratio were estimated. The results showed that the technical efficiency indices of the producers surveyed varied between $11 \%$ and $91.1 \%$ with an average of $45.62 \%$. Soybean production is financially profitable depending on the level of technical efficiency although the yields obtained are very low for each of the groups. The profit to cost of production ratio revealed that the group of the most efficient producers has the best ratio (1.18> 0.93 ), showing that soybean producers are technically inefficient overall. With regard to the indicators, they are far from the production potential expected in Benin.
\end{abstract}

Keywords: Soybeans, technical efficiency, financial profitability, agricultural production system, legume

\section{Introduction}

According to (Debruyne, 2010, 815-819), (Koopmans, 1951, 185-208) and (Farrell, 1957, 253-290) are predicted to be the founders of the measurement of technical efficiency. For them, technical efficiency is achieved when, for a given level of production, it is impossible to obtain a larger quantity produced with the same quantities of inputs. However, not all companies are fully efficient (Biaou \& Saliou, 2018, 16). Technical efficiency is which who linked to the performance capacity of a production unit in a given context. According to (Kocisova, 2015, 12), the theory of technical efficiency was proposed by Koopmans in the years 1951. For him a producer is technically efficient if an increase in his production requires a reduction of at least one other production or an increase of at least one entry and whether a reduction of one entry will require an increase of at least one other entry or a reduction of at least one exit. There are several approaches to measuring effectiveness. However, two of them are the most used. The Stochastic Frontier Approach (SFA) created by (Aigner \& al, 1977, 15) and the Data Envelope Analysis (DEA) approach developed by (Charnes \& Coll, 1978, 12). The theory of technical efficiency is not static and scientists keep perfecting it. Technical efficiency is concerned with how the production process turns inputs into outputs. Thus, technical efficiency measures the ability of a production unit to obtain the maximum possible outputs from a combination of inputs and a given production technology or its ability to achieve a level of output. It is therefore the relationship between verified production and production that could be obtained if the operation were fully efficient. Thus, technical inefficiency therefore corresponds either to production below what is technically possible for a quantity of inputs and a data technology. 
The economic growth potential of Sub-Saharan African countries, including Benin, depends largely on the agricultural sector (Chogou et al., 2018b, 13). However, for two decades, the contribution of Beninese agriculture to the Gross Domestic Product (GDP) has fluctuated and has averaged $27.8 \%$ with a downward trend (DSA-MAEP, 2020). Also, the recent food crises of 2009 have amplified the vulnerability of the economy through that of agriculture, which depends mainly on cotton mono-production (Chogou et al., 2018b, 13). In fact, almost half of the country's municipalities are chronically food and nutritional insecure due to insufficient food available to the population (Oloumilade \& Yabi, 2020, 26). As a result, the Beninese agricultural sector, although not very diversified, has been identified as the main engine of economic growth.

To strengthen the achievements and allow this sector to play its role more, the government has drawn up a strategic plan for the development of the agricultural sector in order to better promote the agricultural sectors by opting for an institutional approach based on the Agricultural Development Poles (ADP) (MAEP, 2019, 104). Following this approach, soybean cultivation has been identified by some (ADP) as a potential source of economic growth. Soy is a legume that is a sustainable food source for both humans and animals because it contains enough nutrients. The promotion of this culture, which began in the 1980s, only experienced real expansion from 2008 with an annual growth rate of $15.6 \%$ during the period 2008-2015 (Chogou et al., 2018a, 18). The soybean sector has proven to be a strategic sector on which certain communes in Benin, notably Tanguiéta, can rely to improve the incomes of rural populations (Bambani, 2020, 67). Indeed, the presence of legumes in agricultural production systems contributes to increasing the functional diversity of agro-ecosystems. This promotes the biodiversity of agricultural landscapes and territories (Schneider et al., 2015, 515). The harmful effects of climate change and soil degradation in certain regions of Benin, particularly in Tanguiéta, can now make the soybean sector an alternative that can positively impact the level of farmers' income. The rural world of the municipality, already vulnerable to the low yield of other crops, benefits from the added value of soybeans, following its production and the various artisanal transformations it offers (Bambani, 2020,67). The combination of legumes and grains creates a stable system that can help protect soil fertility and reduce chemical input dependency factors, while producing high yields (Althouse et al., 2019, 7). The rural incomes of men and women come mainly from the processing and marketing activities of soybean by-products in various forms. It is necessary to assess the efficiency of soybean production in Tanguiéta.

Several methods and approaches to assess the efficiency of agricultural production systems have been developed and used in empirical studies. Therefore, of these approaches, two are the most used to assess effectiveness. These are the parametric approach and the non-parametric approach. If it is considered that the production system can be represented by explicit parameters as in the case of the Cobb-Douglas function, the adopted approach is qualified as parametric. Otherwise, the non-parametric approach is more suitable for evaluating efficiency (Bambani, 2020, 67). Several studies on measuring the efficiency of agricultural producers simply measure technical efficiency indices without establishing a link with financial profitability. However, the latter represents a much more accessible and understandable indicator (Chogou et al., 2018a, 18). It also makes it possible to better assess the efficiency of agricultural systems. Is there a correlation between the level of efficiency and financial profitability in agricultural production? The objective of this study was to assess the profitability and Technical efficiency of soybean producers in the municipality of Tanguiéta.

\section{Research Questions and Hypotheses}

This article explores the relation between technical efficiency and financial profitability of soybean producers in the municipality of Tanguiéta. The questions the authors raise are:

- How to evaluate the level of technical efficiency of soybean producers in the municipality of Tanguiéta?

- How to analyze financial profitability according to the level of technical efficiency of soybean producers in the municipality of Tanguiéta?

To answer the above questions, we pose the following hypotheses:

- H1: Soybean producers in the municipality of Tanguiéta are technically inefficient;

- H2: Soybean production in the municipality of Tanguiéta is financially profitable depending on the level of technical efficiency of producers.

\section{Methodology}

\subsection{Description of the Study Area}

The study was conducted with soybean producers in the Municipality of Tanguiéta which is located in the agricultural development pole3 in the Northwest region of the Atacora. Department, between $10^{\circ} 37^{\prime} 0^{\prime}$ ' 'North 
latitude and $1^{\circ} 16^{\circ} 0 "$ East longitude. It covers an area of $5,465 \mathrm{~km} 2$ and being in two distinct physical environments: the Atacora Plain and the Atacora Range to the Northwest and West respectively. It is bounded to the north by the pendjari, to the east and south east by the municipalities of Toucountouna and Boukombé; and to the west by the municipalities of Materià and Cobly. The climate is Sudano-Sahelian with a rainy season which goes from May to November and a dry season which covers five (05) months (from December to April). Formerly dense, the vegetation of the municipality of Tanguiéta has undergone strong anthropogenic pressure (agriculture, wildfire, construction, etc.) and has given way to a mixture of shrub, herbaceous and sparse savannas. The main forest species that we meet are: baobab (Adansonia digitata), palm tree (Borassus aethiopium), shea (Vittellaria paradoxa), cheese (Ceiba pentandra), néré (Parkia biglobosa) and mango (Mangifera) indica). The relief is of two types: the Gouma peneplain to the west and the Atacora chain to the east with varying altitudes between 200 and $400 \mathrm{~m}$. The most common soils are lateritic, gravelly, clayey, sandy loam, sandy clay, loamy, sandy loam and ferruginous. The municipality has thirty-nine (39) villages and city districts, spread over five (5) districts: Tanguiéta, Taïacou, Cotiakou, N'Dahonta and Tanongou (Figure 1). The Municipality of Tanguiéta had a total population of 74,645 inhabitants until 2013 (RGPH-4, 2013).

The Municipality is an area where the natural environment has been subjected to strong pressure from its inhabitants, who derive most of their income from agricultural activities. It goes without saying that the dominant economic activity in this study environment is agriculture, which occupies $80 \%$ of the population (Kombienou et al. 2020). The cultivation of cereals (maize, sorghum, millet, etc.) is predominant in the town. In addition, cash crops are on the rise, with a view to increasing the economic power of the populations. For example, the cultivation of cotton and certain legumes (soybeans, cowpeas, voandzou, beans, peanuts). Always with a view to improving their income, the populations are also developing the trade in livestock, poultry (sheep, cattle, pigs, goats, chickens, guinea fowl) and market gardening at the foot of the mountains (tomatoes, cabbage, carrots). Thus, every day, tomatoes, carrots and other market garden products descend from the mountains to supply the market in the municipality. Hunting and fishing are also developed by the villages bordering the Pendjari National Park. These activities have both economic, social and environmental impacts. The economic impacts revolve around the income of the populations. The social impacts relate to improving the conditions and living environments of the populations. As for the environmental impacts, they are multiple and concern the degradation of the plant cover, the impoverishment of the soil and the decline in agricultural yield (Edalo et al. 2019)

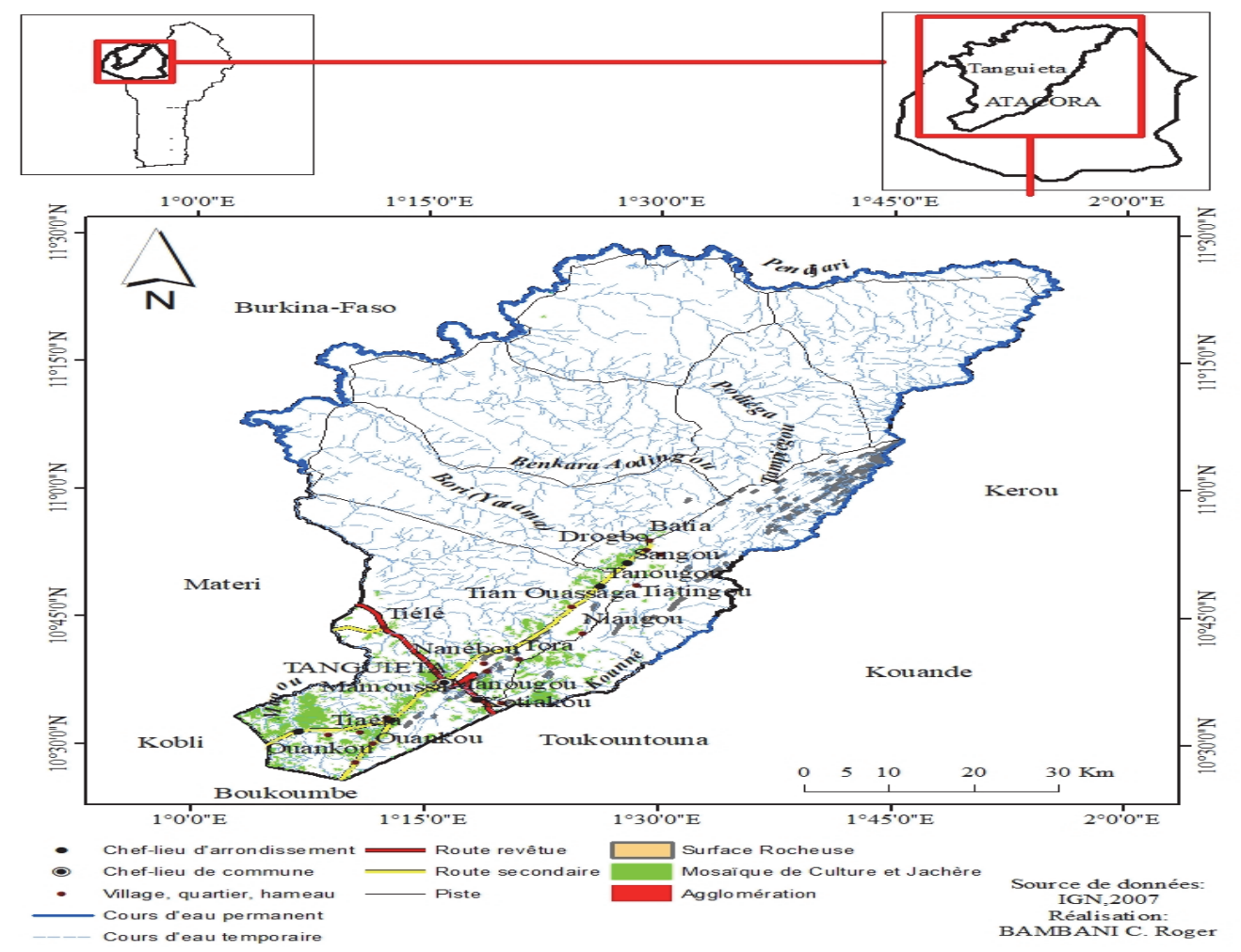

Figure 1. Administrative map of the municipality of Tanguieta 


\subsection{Technical Sampling and Size of Appraised}

The research units for the study were households or soybean producers in Tanguiéta. At the level of each District, two to three villages were drawn at random. At the level of each of the villages thus drawn, the enumeration of soybean producers only and or in association with other crops such as corn and sesame was done with the help of the representative of the producers identified at the level of each district. Subsequently, a population consisting only of mono-crop soybean producers at the level of all the selected villages was defined. To constitute the sampling frame, a random selection was carried out at the level of the predefined stratum (population). To this end, a stratified sampling frame of at least 300 producers was established. This database made it possible to determine, using a preliminary questionnaire, the number of producers who actually produced soybeans during the 2019-2020 crop year. These 184 producers $(61.33 \%)$ represented the final sampling. (See Tables 1$)$.

Table 1. Study Sampling

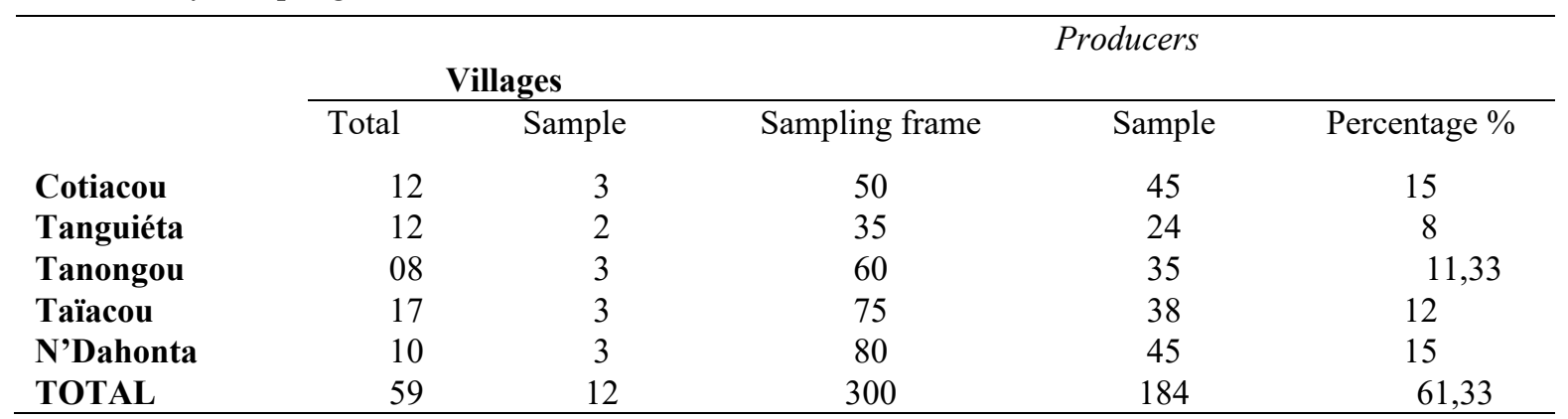

Source: INSAE (2013) and Authors, November 2020.

\subsection{Type of Data, Sources and Method of Data Collection}

The data used in this study were both qualitative and quantitative. They were from primary and secondary sources. Primary data was collected during the survey of sampled soybean producers. These were the data relating to the inputs and outputs of production. This includes, among other things, information on fixed cost elements (agricultural tools and equipment, their price and lifespan); variable cost elements (inputs, labor); and agricultural income items (products and their selling price). The secondary data were collected by a documentary review.

\subsubsection{Method for Estimating Technical Efficiency Parameters}

The production costs were obtained from the physical quantities of the different inputs and their prices. The various elements entering into the constitution of the operating account of a farmer were: the gross product (GP), the production cost (intermediate consumption, the variable charge, the fixed charge). The indicators that could be calculated to assess the financial profitability of a farm: margin on variable cost, added value, agricultural income, net margin, profit / cost ratio, etc.).

\subsubsection{Method for Calculating Financial Profitability Parameters}

\subsubsection{Financial Profitability}

It is a financial analysis indicator that expresses the total financial gain obtained by the investment of one monetary unit (\$1) (Dao et al., 2019). Let B be the set of benefits obtained after a total investment $C$. It then comes back to: $\mathrm{RF}=\mathrm{B} / \mathrm{CT}$. In agricultural economics, B is denoted by the gross product obtained in value and CT by the set of all costs expressed in value, including family labor.

\subsubsection{Different Phases of the Study}

All scientific knowledge is formalized using a well-developed methodology so that the plausibility of the results can be demonstrated based on experiments and logical arguments. It is a combination of qualitative and quantitative research approaches.

\subsubsection{Phases of the Study}

The present study took place in three (03) phases namely: the preparatory phase or documentary review, the exploratory phase and the final investigation phase.

The documentary review constitutes the basis of any scientific study. It enables information to be capitalized for theoretical knowledge. During this stage, the available literature (dissertations, theses, articles, scientific research 
sites) on the study theme was used. It provided an understanding of the technical aspects used by soybean producers in the study environment initially, then the economic aspects not yet or not sufficiently explored in terms of profitability of soybean production in the municipality of Tanguiéta.

After defining the objectives of the study on the basis of the documentation mobilized, an exploratory research phase was necessary for two major reasons. The first was to collect general information from the field in order to verify the feasibility of the study. The second was to be able to meet the producers and other resource persons for discussions in order to make a judicious choice of variables and measurement indicators and for a good sampling in order to conduct the study well. Consequently, during this phase, agricultural advisers, resource persons and soybean producers from all the villages of the municipality were visited. Semi-structured, individual and group interviews were carried out in the five districts of the municipality using an interview guide and a preliminary questionnaire.

Final investigation phase is the actual investigation phase. The aim is to collect data at the level of the survey units that constitute the soybean producers in the municipality. The methods used are, among others, structured interviews with the questionnaire as the main tools, semi-structured interviews and finally participant observations to better understand and analyze the data.

\subsubsection{Estimation of Technical Efficiency}

\subsubsection{General Model for Estimating Technical Efficiency}

In an economy where the availability of resources is limited, the notion of technical efficiency takes an increasingly important place in scientific debates and research (Ghali et al. 2013). It gives an indication of the capacity of companies to make the most adequate use of existing technology and to avoid wasting resources. In the context of the present study, the option was made for a parametric approach to measure the technical efficiency of soybean producers in the study area. As a reminder, this approach is recommended when it comes to sectors for which there is a fairly clear idea of what technology is, especially in agriculture (Ambapour, 2001). It imposes a functional form to specify the production function, the cost function or the profit function. Econometric tools were used to estimate the stochastic parametric model of the Cobb-Douglas type production function estimation.

The econometric equation which will make it possible to estimate technical efficiency indices in general is as follows:

Lny $_{\mathrm{i}}=\beta_{0}+\beta_{\mathrm{k}} \ln \sum\left(\mathrm{x} \_\mathrm{ki}\right)+\left(\mathrm{v}_{\mathrm{i}}+\mathrm{u}_{\mathrm{i}}\right)$

$\mathrm{i}$ indicates the observation made on the ith production $(\mathrm{i}=1,2,3,4 \ldots . \mathrm{N})$

$\mathrm{Y}$ represents the quantity (in $\mathrm{Kg}$ )

$\mathrm{X}_{\mathrm{k}}$ represents the factors of production;

$\mathrm{Vi}$ represents random variables beyond the control of producers and $U_{i}$ represents random variables expressing technical inefficiency $\boldsymbol{\beta}$ and $\sigma$ are parameters to be estimated. The $\sigma^{2}$ will give the variance ratio $\gamma$ which is between ( 0 and 1) $\gamma$ is given by $\gamma=\sigma u^{2} / \sigma s^{2}$ with $\sigma s^{2}=\sigma u^{2}+\sigma v^{2}$ the technical efficiency is given by $\mathrm{TE}_{\mathrm{i}}=\mathrm{e}^{(-\mathrm{ui})}$

More specifically in the context of this study, the following model for measuring technical efficiency is used.

3.3.4.2 Specification of the Model for Estimating the Level of Technical Efficiency of Soybean Producers

LnPRODUCTION $_{i}=\beta_{0}+\beta_{1}$ LnSUPERFICIE $_{i}+$ B $_{2}$ LnSEMENCE $_{i}+$ B $_{3}$ LnTRAVAIL $_{i}+\beta_{4}$ Ln CAPITAL $_{i}+$ V $_{i^{-}}$ $\mathrm{U}_{\mathrm{i}}$

with $i=1,2,3, \ldots \ldots . . . n$, ( $n$ being the size of the sample);

$\beta_{\mathrm{J}}(\mathrm{j}$ the vector of unknown parameter to be estimated, $\mathrm{j}$ ranging from 0 to 4 ).

The random term $V_{i}$ will designate factors that have escaped the control of exploitation such as the economic environment, climate change, floods, the effects of world prices, the invasion of devastating insects or birds,.... etc., to measurement errors of any other statistical error. The $U_{i}$ will represent the random variable translating the technical inefficiency in terms of production of farm $i$. By assumption the $V_{i}$ will be independently and identically distributed according to the normal law $\left(0, \sigma^{2}\right)$, and the $U_{i}$ will be defined positively with an asymmetric distribution independent of that of the $\mathrm{V}_{\mathrm{i}}$. The $\mathrm{U}_{\mathrm{i}}$ will follow a semi-normal, zero-truncated normal distribution, or exponential distributions. The parameters of the stochastic production frontier are estimated by the Maximum Likelihood Method 
Table 2. Description of frontier production variables

\begin{tabular}{ll}
\hline VARIABLES & \multicolumn{1}{c}{ DESCRIPTION } \\
\hline Production & Total harvested soybean production $(\mathrm{Kg})$ by producer i \\
Area & Area cultivated with soybeans by producer i (expressed in hectare ha) \\
Seed & Quantity of seed used in Kg by producer i \\
Job & Total quantity of labor used in man-days by producer ii \\
Capital & All fixed costs and variable costs used (organic fertilizer, minerals, herbicides and \\
& insecticides) by producer i
\end{tabular}

Source: Authors

Following the result of the estimation of the technical efficiency level of producers, the efficiency indices resulting from this model were used to constitute two categories of producer groups. The most efficient producers and the average or weakly efficient producers whose technical efficiency scores are less than or equal to $50 \%$ (Group 1 and Group 2).

\subsection{Methods of Data Analysis}

\subsubsection{Statistical Descriptions (Assessment of Financial Profitability Parameters)}

To assess the financial profitability indicators calculated during the study, recourse was made to statistical models. Analysis of variance (ANOVA) is a statistical method which makes it possible to study the modification of the mean $\mu$ of the phenomenon studied Y (quantitative variable) according to the possible influence of one or more qualitative experience factors (Atchade et al. 2018). If the mean is influenced by only one factor (noted as factor $\mathrm{X}$ ), it is a one-way Analysis of Variance. On the other hand, two-way Analysis of Variance can be considered as a generalization of one-way analysis of variance allowing two factors to be taken into account simultaneously. Overall, the conditions for applying the two-factor analysis of variance are the same as for a single factor: normal populations, of the same nature and simple and independent samples.

\subsubsection{Econometric Analysis: Analysis of the Financial Profitability of Soybean Production}

Given the estimated technical efficiency indices and the analysis of the variance of the financial profitability parameters, a comparative approach of the means was made using the Tukey method. This method uses the Tukey HSD test and provides confidence intervals for the differences between parameters $\alpha_{\mathrm{i}}-\alpha_{\mathrm{j}}$ or $1 \leq \mathrm{j}<\mathrm{j} \leq \mathrm{I}$. This test will be done at the level of all the producers in the study sample. The main analysis software was software R. It made it possible to highlight the differences between the means of the estimated profitability parameters, the limits of the confidence intervals and the probabilities of significance at the thresholds of $(* * * * 0 \%, * * * 0.01 \%, * * 1 \%$ and $* 5 \%$ ) in order to compare these profitability parameters. The methodology was based on the same study area. The sample defined for this study was used for both hypotheses. However, each hypothesis has its base of variables to constitute, its own model and its own analysis tools.

\subsubsection{Technical Efficiency Model (Analysis of Technical Efficiency Scores)}

The estimation of the model defined above made it possible to determine the technical efficiency indices of each producer using the StataSE13 software (64-bit). Thus, the scores of the technical efficiency indices estimated from the previously defined stochastic model were used to constitute two groups of soybean producers.

\section{Results}

\subsection{Assessment of the Level of Technical Efficiency of Soybean Producers}

\subsubsection{Demographic Characteristics of the Respondents (Sex, Age)}

Analysis of Figure 2 revealed that roughly an equivalence between male (50.54\%) and female (49.46\%) soybean producers among respondents. This showed that soybean cultivation was practiced by both men and women in the study area. The minimum age for producers was 18 and the maximum was 74 for all respondents. The average age of the producers surveyed was 37 years with a variability of $12.054(\sigma=12.05414)$. The majority of producers were married (78.46\%) against (11.28\%) widows and widowers and (10.25\%) single. 


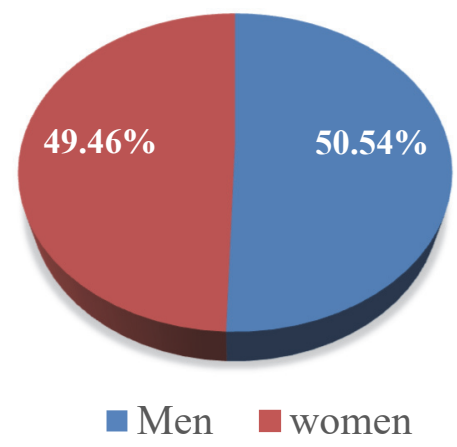

Figure 2. Distribution of respondents by gender

4.1.2 Result of the Estimation of the Stochastic Production Function

The following is about the results of the estimation of the stochastic production function (see Table 3).

Table 3. Result of the estimation of the econometric model of the stochastic function

\begin{tabular}{lllll}
\hline VARIABLE & PARAMETER & COEFFICIENT & TYPE ERROR & $\begin{array}{l}\text { STATISTICAL } \\
\text { VALUE }\end{array}$ \\
\hline Constancy & beta 0 & $0.21604422 \mathrm{E}+01$ & $0.10178059 \mathrm{E}+01$ & $0.21226465 \mathrm{E}+01$ \\
& & & & \\
Area & beta 1 & $0.24321572 \mathrm{E}-09$ & $0.34358253 \mathrm{E}-09$ & $-0.70788151 \mathrm{E}+00$ \\
Seed & beta 2 & $-0.37444938 \mathrm{E}-09$ & $0.41419986 \mathrm{E}-09$ & $-0.90403066 \mathrm{E}+00$ \\
Job & beta 3 & $0.20945610 \mathrm{E}-09$ & $0.98912206 \mathrm{E}-09$ & $0.21175961 \mathrm{E}+01$ \\
Capital & beta 4 & $-0.35114311 \mathrm{E}-08$ & $0.11251420 \mathrm{E}-08$ & $-0.31208782 \mathrm{E}+00$ \\
Sigma square & & $0.025315353 \mathrm{E}$ & $0.32120983 \mathrm{E}+00$ & $0.78812510 \mathrm{E}+01$ \\
Gamma & & $0.89676426 \mathrm{E}$ & $0.25965463 \mathrm{E}-01$ & $0.34536810 \mathrm{E}+02$ \\
Log likelihood & & $-0.25906175 \mathrm{E}+03$ & - & - \\
Likelihood ratio & & $0.63191226 \mathrm{E}+02$ & - & - \\
test (LR) & & & - & - \\
$\begin{array}{l}\text { Medium } \\
\text { technical }\end{array}$ & & 0.4562 & & \\
efficiency & & & & \\
\hline
\end{tabular}

Source: Authors based on survey data, November 2020

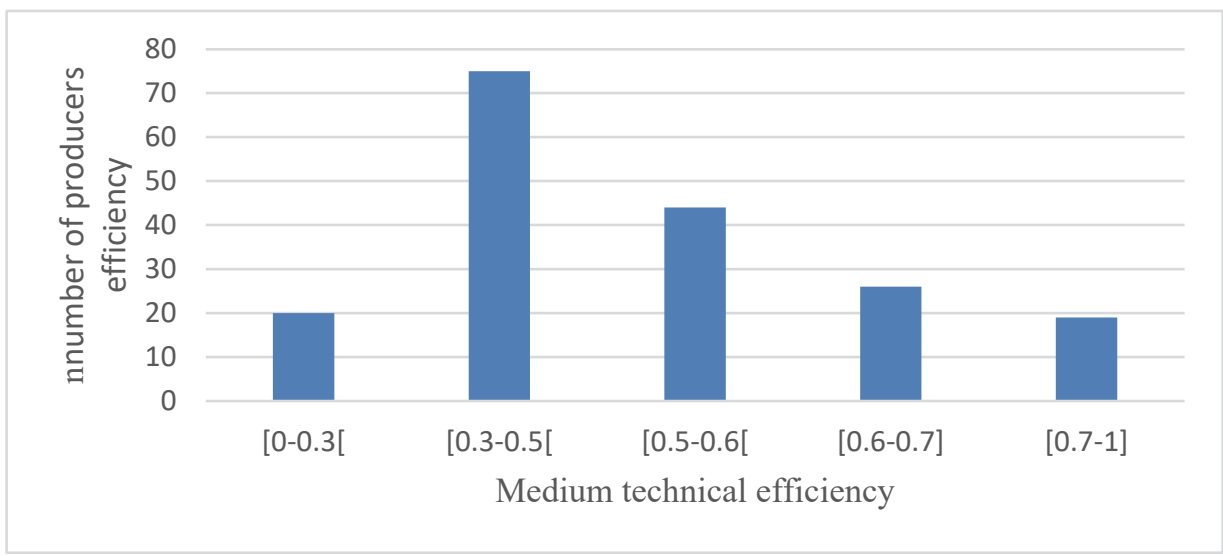

Figure 3. Distribution of producers according to their technical efficiency index

The analysis of Table 4 relating to the average level of technical efficiency of producers, showed that the value of gamma $\delta=0.89$ was significantly different from zero. The value $\gamma=0.89$ showed that $89 \%$ of the variation in 
soybean production in the study area was due to technical inefficiency of producers and the remaining $11 \%$ of this variation was due to random factors including measurement errors, which could result from the nature of the data. In addition, reading the technical efficiency scores estimated from the model and the distribution graph of producers according to their technical efficiency index (figure 2) showed that a large part of the producers surveyed had a technical efficiency of less than $50 \%$. This was all the more explained by the fact that all the producers had an average technical efficiency of $45.62 \%$ in accordance with the results obtained from the estimation of the stochastic production function. Indeed, these results had certain technical implications. First, the existence of significant inefficiency levels (about $50 \%$ of the respondents in the sample had an efficiency level below the average) was synonymous with the existence of improvements to be made concerning soybean cultivation practices in the region municipality of Tanguiéta. Almost all of the producers surveyed did not receive any training or advisory support on production techniques for legumes in general and soybeans in particular (Table 4). However, with these technical efficiency scores, the vast majority of soybean producers could improve their yields under the constraints of available resources (inputs). The level of technical efficiency being assessed and showing a significant proportion of producers with inefficiencies in soybean production, room for maneuver remained possible to improve their yields without increasing their input levels or to save on current costs. of production. However, the factors which constituted pockets of ineffectiveness or inducing efficiency should be identified for actions

\subsubsection{Socio-Economic Characteristics of the Respondents}

After determining the scores, the technical efficiency indices of all the respondents selected following the preliminary questions were grouped according to their technical efficiency levels. However, group 1 was that of producers who obtained technical efficiency scores between $10 \%$ and $51 \%$ excluded. They have been described as technically poorly efficient producers. They numbered 103 and constituted $55.97 \%$ of respondents. As for group 2 , it represented all the producers who obtained technical efficiency scores greater than or equal to $51 \%$. They have been described as the most technically efficient producers. They constituted $44.06 \%$ of the respondents.

Table 4. Socio-economic characteristics of the producers surveyed

\begin{tabular}{|c|c|c|c|c|}
\hline \multirow{3}{*}{ VARIABLES } & \multicolumn{2}{|c|}{ PRODUCERS } & \multirow{2}{*}{\multicolumn{2}{|c|}{ TOGETHER }} \\
\hline & \multicolumn{2}{|c|}{ EFFICIENCY LEVEL } & & \\
\hline & GROUP1 & GROUP2 & & \\
\hline \multirow[t]{2}{*}{ Number of observations } & 103 & 81 & \multicolumn{2}{|c|}{$184(100 \%)$} \\
\hline & & & & Pro $>t$ \\
\hline Household size & 8 & 8 & 8 & 0,412 \\
\hline Number of agricultural workers & 3,13 & 3,27 & 3,23 & 0,017 \\
\hline No education level & $48(46,6 \%)$ & $51(62,9 \%)$ & $99(53,8 \%)$ & \\
\hline Primary level & $32(3 \%)$ & $19(23,5 \%)$ & $51(27,7 \%)$ & \\
\hline Secondary level & $16(15,5 \%)$ & $9(11,1 \%)$ & $25(13,6 \%)$ & 0,126 \\
\hline University level & $7(6,7 \%)$ & $2(2,5 \%)$ & $9(4,9 \%)$ & \\
\hline Technical training received & $9(8,7 \%)$ & $8(9,8 \%)$ & $17(9,2 \%)$ & 0,404 \\
\hline $\begin{array}{l}\text { Average technical efficiency } \\
\text { level }\end{array}$ & $\leq 0,50$ & $>0,50$ & 0,4 & \\
\hline
\end{tabular}

Source: Authors based on survey data, November 2020

\subsubsection{Results of the Estimation of Socio-Economic Variables}

- Results of the estimation of the Tobit econometric model of socio-economic variables (all respondents)

$$
\begin{aligned}
& \operatorname{LR} \operatorname{chi} 2(3)=8.30 \\
& \text { Prob }>\text { chi } 2=0.0401 \\
& \text { Log likelihood }=84.395897 \quad \text { Pseudo R2 }=-0.0517
\end{aligned}
$$

et $\mid$ Coef. Std. Err. $\quad \mathrm{t} \quad \mathrm{P}>|\mathrm{t}| \quad$ [95\% Conf. Interval $]$ 


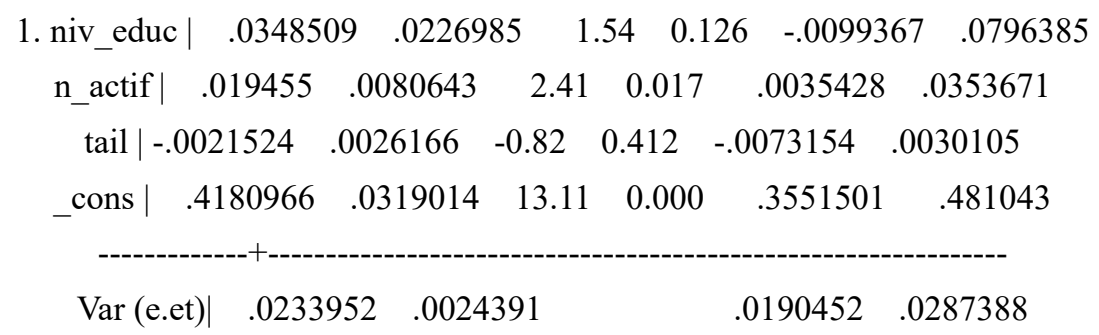

Source: Authors based on survey data, November 2020

- Results of the Tobit econometric model estimation of socio-economic variables (group $\mathrm{n}{ }^{\circ} 1$ )

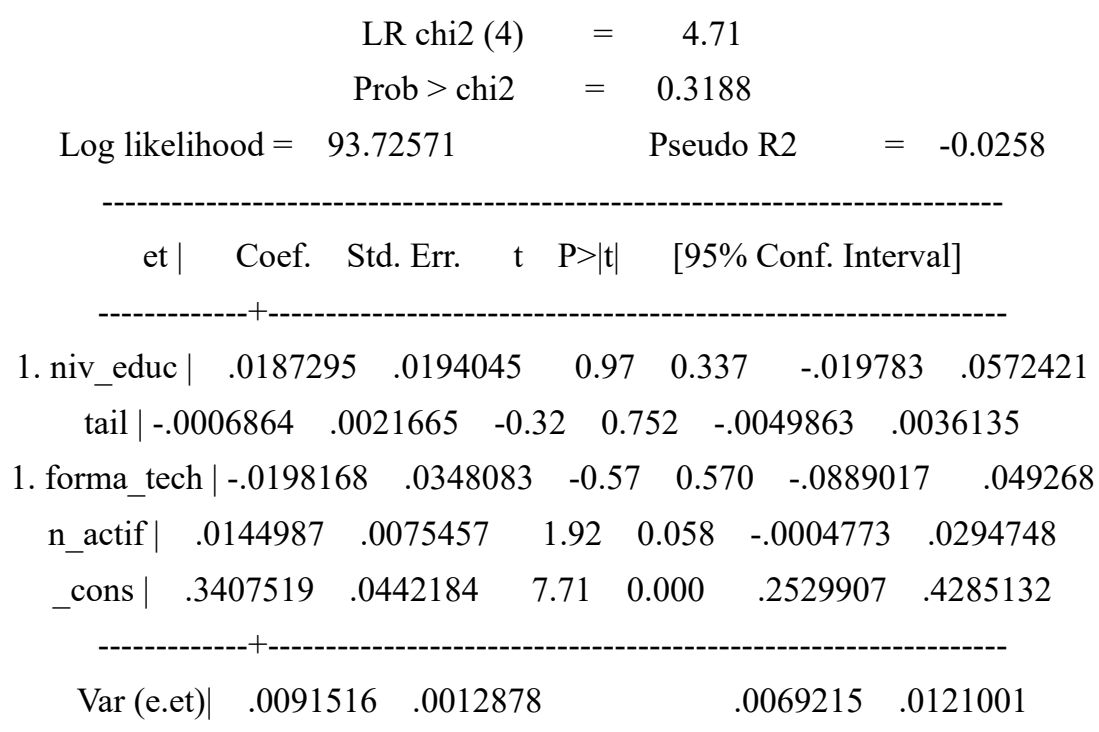

Source: Authors based on survey data, number 2020

- Results of the Tobit econometric model estimation of socio-economic variables (group $n{ }^{\circ} 2$ )

$$
\begin{aligned}
& \text { LR chi2 (3) }=3.28 \\
& \text { Prob }>\text { chi } 2=0.3503 \\
& \text { Log likelihood }=83.605845 \quad \text { Pseudo R2 }=-0.0200 \\
& \text { et } \mid \text { Coef. Std. Err. } \quad \mathrm{t} \quad \mathrm{P}>|\mathrm{t}| \quad \text { [95\% Conf. Interval] }
\end{aligned}
$$

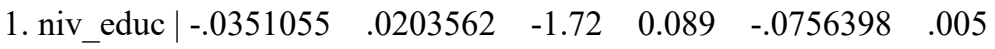

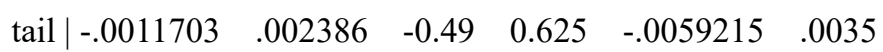

$$
\begin{aligned}
& \text { 1. forma_tech } \mid \begin{array}{llllll}
0233516 & .0328426 & 0.71 & 0.479 & -.0420463 & .0887
\end{array} \\
& \begin{array}{lllllll}
\text { _cons } \mid & .6289877 & .0354241 & 17.76 & 0.000 & .5584493 & .6995
\end{array} \\
& \begin{array}{lllll}
\operatorname{Var}(\mathrm{e} . \mathrm{et}) & .0072408 & .0011449 & .0052851 & .0099202
\end{array}
\end{aligned}
$$

Source: Authors based on survey data, November 2020

The analysis of Table 5 and the various results of the Tobit econometric model tests showed that the size of the household, the level of education and the technical training received by the producers were not significant at the level of the whole producers. These variables did not significantly differentiate the level of technical efficiency 
and the output of producers $(\mathrm{P}>5 \%)$. The majority of producers $(90.8 \%)$ did not receive specific training regarding soybean production in the study area. While it was true that for all the producers surveyed, the level of education was not significant, it was noticed that after the econometric test of the Tobit model of group 2, this variable was found to be significant in $10 \%$ threshold. It was found that the level of education positively influenced the technical efficiency of producers in this group. The comparison of the number of assets allocated at the level of the two groups and at the level of all producers showed that this variable significantly influenced at the $10 \%$ threshold the level of technical efficiency of the producers surveyed.

\subsection{Analysis of the Profitability of Soybean Production According to the Level of Technical Efficiency}

Before analyzing the financial profitability of the soybean production of the producers sampled as part of the study, the average agronomic performance indicators for each group of producers were determined. These average indicators were calculated using statistical software R.

4.2.1 Average Agronomic Performance Indicators of Producers

Table 5. Producer performance indicators

\begin{tabular}{lccc}
\hline \multicolumn{1}{c}{ VARIABLES } & GROUP OF PRODUCORS & TOGETHER \\
\cline { 2 - 3 } & Group 1 & Group 2 & 658,88 \\
Production in Kg & 639,7 & 684,2 & 0,671 \\
Area sown (ha) & 0,730 & 0,595 & 1067,3 \\
Yield (Kg / ha) & 959,2 & 1204,8 & 148.248 \\
Gross product (FCFA) & 191.910 & 188.55 & 220.935 \\
Gross product (FCFA / ha) & 262.890 & 316.227 & 225 \\
Sale price in FCFA & 300 & 275 & \\
\hline
\end{tabular}

Source: Authors based on survey data, November 2020

The analysis in Table 6 revealed that, the producers in group 2 were the most efficient even if the average agronomic performance indicators obtained were slightly higher than those of all the producers surveyed.

Table 6. Tukey statistical comparison test on agricultural indicators

\begin{tabular}{lllll}
\hline \multicolumn{1}{c}{ VARIABLES } & \multicolumn{1}{c}{$\begin{array}{c}\text { Diff } \\
\text { (Ecart-type) }\end{array}$} & \multicolumn{1}{c}{ lwr } & Upr & F $>\mathrm{t}$ \\
\hline Production in Kg & 652.789 & 236.501 & 889.365 & $0.0304^{*}$ \\
Area sown (ha) & -0.1539031 & -0.308422 & 0.000616133 & 0.0509109 \\
Yield (Kg / ha) & 248.3925 & 187.7424 & 309.0426 & $0 * * * *$ \\
Gross product & 6273.529 & -21383.82 & 33930.88 & 0.6550062 \\
\multicolumn{1}{c}{ Gross product / ha } & 55838.64 & & & 0 \\
\hline
\end{tabular}

Source: Authors based on November 2020 survey data

Meaning at $0 \%$ '****' $0.01 \%$ '***, $1 \%$ ‘**, $5 \%$ ‘*,

The analysis of Table 7 showed that, the quantity of soya produced was significant at the 5\% level $(\mathrm{F}=0.0304)$, the maximum limit of the confidence interval being $889.365 \mathrm{Kg}$, this supposes that the producers weakly efficient could increase their production up to $889.365 \mathrm{Kg} /$ ha if they improved their technical efficiency levels. Also, the cross-analysis of Tables 5 and 6 showed that the variables (area sown and gross product) did not vary significantly according to the group regardless of the level of technical efficiency of the producer. Tukey's $F$ test of comparison of means confirmed this assertion with Fisher's probabilities $(\mathrm{F}>5 \%)$. As for the yield and the gross product per hectare, they varied significantly at the $0 \%$ threshold depending on the level of technical efficiency of the soybean producers surveyed. The $\mathrm{F}$ test of comparison of means confirmed this assertion with Fisher probabilities $(\mathrm{F}=0 \%)$ for these two variables. This significant difference in yield per hectare obtained by producers in group 2 was explained by their level of technical efficiency, which was higher than the average $(45.62 \%)$ of all the producers surveyed. However, group 1 producers would improve their yield if they could increase their level of technical 
efficiency to the threshold of group 1 producers. It was noted that all of the producers surveyed had used the improved soybean varieties. In addition, the selling prices of the producers surveyed were between 175 FCFA and $395 \mathrm{FCA} / \mathrm{Kg}$.

However, the less efficient producers preferred to store their productions and sell at the average price of 300 FCFA $/ \mathrm{kg}$, while the most efficient producers preferred to sell their productions at the average price of $275 \mathrm{FCFA} / \mathrm{kg}$. It was pointed out that when the data was collected, no producer was ready to sell his production at the price of 175 FCFA set by the State on behalf of this agricultural season. There was a difference between producers on the valuation of soybeans. Despite this commercial policy, the gross product per hectare of producers in group 2 was higher than that of producers in group 1 (316,227 FCFA $>262,890$ FCFA). The analysis of variance test and the comparison of Tukey means test confirmed this with a Fisher probability $(\mathrm{F}=0 \%)$. The gross product per hectare was then positively correlated with the level of technical efficiency of the producer. Group 1 producers had an interest in improving their technical efficiency levels if they wanted to improve their raw products in order to better cover their production costs.

\subsubsection{Treatment of Production Costs by Group of Producers Surveyed}

Table 7. Soybean production costs

\begin{tabular}{lccc}
\hline & \multicolumn{3}{c}{ PROCESSING OF PRODUCTION CHARGES } \\
\cline { 2 - 4 } WORDING & GROUP1 & GROUP2 & TOGETHER \\
Column1 & Colonne2 & Colonne3 & Colonne4 \\
Plowing costs & 20026,70 & 17944,44 & 19110,05 \\
Seed purchase & 17532,82 & 14302,22 & 16110,65 \\
Seed planting costs & 5594,18 & 4898,15 & 5287,77 \\
Purchase of herbicide & 3300,97 & 2074,07 & 2760,87 \\
Weeding costs & 7578,43 & 6413,58 & 7062,84 \\
Harvest costs & 8629,13 & 7027,16 & 7923,91 \\
Ginning costs & 8701,94 & 5718,52 & 7388,59 \\
Transport costs & 6146,60 & 5561,73 & 5889,13 \\
Packing costs & 1599,37 & 1708,03 & 1647,20 \\
Total variable loads (CVT) & $\mathbf{7 9 1 1 0 , 1 4}$ & $\mathbf{6 5 6 4 7 , 8 9}$ & $\mathbf{7 3 1 8 1 , 0 2}$ \\
Variable load / ha (CV / ha) & 108370,05 & 110332,59 & 109062,62 \\
Estimated family labor & 20378,64 & 20543,21 & 20451,09 \\
Fixed charges (CF) & $\mathbf{2 0 3 7 8 , 6 4}$ & $\mathbf{2 0 5 4 3 , 2}$ & $\mathbf{2 0 4 5 1 , 0 9}$ \\
Fixed charges / ha (CF / ha) & $\mathbf{2 7 9 1 5 , 9}$ & $\mathbf{3 4 5 2 6 , 4 0}$ & $\mathbf{3 0 4 7 8 , 5 2}$ \\
Global charges & $\mathbf{9 9 4 8 9}$ & $\mathbf{8 6 1 9 1 , 1 0}$ & $\mathbf{9 3 6 3 2 , 1}$ \\
Global loads / ha & 136286 & $\mathbf{1 4 4 8 5 9}$ & $\mathbf{1 3 9 5 4 1 , 1 4}$ \\
Intermediate Consumption (CI) & & & \\
Seed purchase & 17532,82 & 14302,22 & 16110,65 \\
& 3300,97 & & 2760,87 \\
Purchase of herbicide & 1599,37 & 1708,03 & 1647,20 \\
Packing costs & 6146,60 & 5561,73 & 5889,13 \\
Transport costs & $\mathbf{2 8 5 8 0}$ & $\mathbf{2 3 6 4 6 , 0 4 7}$ & $\mathbf{2 6 4 0 7 , 8 5}$ \\
TOTAL OF CI & & & \\
\hline
\end{tabular}

Source: Authors based on survey data from November 2020

Table 8. Tukey statistical comparison test on the operating account indicators 


\begin{tabular}{lllll}
\hline VARIABLES & $\begin{array}{l}\text { DIFF } \\
\text { (STANDARD } \\
\text { DEVIATION) }\end{array}$ & & UPR & $\mathrm{F}>\mathrm{t}$ \\
& -14871.86 & -28932.42 & -811.3023 & $0.0382874^{*}$ \\
\hline Variable expenses & 386.0963 & -1697.129 & 2469.322 & 0.7150262 \\
Fixed charges & 21145.39 & 5226.585 & 37064.19 & $0.0095112^{* * *}$ \\
Variable cost margin (MCV) & 76114.881 & 28866.76 & 104981.66 & $0,048368^{*}$ \\
Global charges & 20759.29 & 5068.966 & 36449.62 & $0.0097939^{* * *}$ \\
Profit &
\end{tabular}

Source: Authors based on survey data, November 2020.

Meaning at $0 \%$ '****' $0.01 \%$ '***' $1 \%$ '**' $5 \%$ '**

Analysis of the data in Table 8 revealed that, the total variable loads showed significant variation between different groups of producers. Tukey's comparison of means test confirmed this with a Fisher probability $(\mathrm{F}<5 \%)$. On the other hand, at the level of the total fixed costs which represented around $20.4 \%$ of the overall production costs, there was no significant difference $(\mathrm{F}>5 \%)$. By comparing the two groups of producers, it was found that those in group 1 had spent more in terms of total variable costs unlike the producers in group 2 . This difference was based on the level of technical efficiency of each group. In other words, the higher the level of technical efficiency, the less the variable production costs increased. In addition, the proportion of semi-plowing costs (47.5\% group1) and (49.1\% group 2) compared to variable costs seemed high at the level of the different groups of producers. This was explained by the nature of the land which had a high stone content and which caused a very high labor cost in terms of plowing costs. The producers surveyed paid occasional workers according to a standard specific to the region. In addition, on behalf of this crop year, the government did not subsidize the price of seeds in the surveyed area. The producers had therefore purchased the seeds at a price of $350 \mathrm{FCFA} / \mathrm{Kg}$ instead of $175 \mathrm{FCFA} / \mathrm{Kg}$ if the government subsidized the seeds. This was also the reason for the increase in variable seed costs compared to total variable costs at the level of the two groups of producers. The average overall costs of all the producers which took into account all the real production costs and the estimated costs (the remuneration of family labor) were established during a production cycle at 93632 FCFA, or 139,541 FCFA / ha. These charges compared to those obtained by (Chogou et al. 2018b) in a similar study in Benin, remained low (185,906 FCFA <139,541 FCFA). Also, when the average unit variable costs (142FCFA / Kg) were compared with the minimum sale price $(175 \mathrm{FCFA} / \mathrm{Kg})$, it was noticed that there was a margin on unit variable cost of (33FCFA / Kg) regardless of the group of producers. Soybean producers had to carry out actions that made it possible to significantly reduce the variable unit cost of production in order to increase their unit margin over variable cost, which remained low. The total costs of production were the sum of the variable costs and the fixed costs. It was noted that the more efficient producers spent relatively less on soybean production compared to the poorly efficient producers. Also, Tukey's test showed that the overall production loads were significant at the $5 \%$ level $(\mathrm{F}=0.04836)$. As a result, poorly efficient soybean producers had to take action to lower their production costs compared to the most efficient producers

4.2.3 Determination of Financial Profitability Indicators

Table 9. Operating account of soybean producers

SOYBEAN GROWERS 'OPERATING ACCOUNT

WORDING

Gross Product (GP)

Cost of Seeds

Cost of Herbicides

Cost of Packaging

Domestic Consumption (CI)
GROUP 1

191910

17532,82

3300,97

1599,37

22433
GROUP2

188155

14302,22

2074,07

1708,03

18084,32
TOGETHER

148248

16110,7

2760,87

1647,2

20518,72 


\begin{tabular}{lcccccc}
\hline Value Added (VAB) & & $\mathbf{1 6 9 4 7 7}$ & & $\mathbf{1 7 0 0 7 0 , 6 8}$ & $\mathbf{1 6 8 7 6 6 , 7 2}$ \\
Added Value (VAB / ha) & & 232160,27 & & 285833 & 251515,231 \\
Gross Variable Loads (CVB) & 79110 & & 65647 & & 73181,02 & \\
Gross Margin (MAB) & & $\mathbf{1 1 2 8 0 0}$ & & $\mathbf{1 2 2 5 0 8}$ & & $\mathbf{7 5 0 6 6 , 9 8}$ \\
Gross Margin (MAB / ha) & & 154520 & & 205896 & 111873 \\
$\begin{array}{l}\text { Global charges } \\
\text { Profit }\end{array}$ & 99489 & & 86191 & & $\mathbf{9 3 6 3 2 , 1}$ & \\
$\begin{array}{l}\text { Production cost } \\
\text { Profit / Cost of Production }\end{array}$ & 99489 & $\mathbf{9 2 4 2 1}$ & & $\mathbf{1 0 1 9 6 4}$ & & $\mathbf{5 4 6 1 5 , 9}$ \\
Ratio & & 86191 & & 93632,1 & \\
\hline
\end{tabular}

Source: Authors based on survey data, November 2020

Analysis of Table 9 showed that the average gross margins per hectare were 154,520 FCFA and 205,896 FCFA respectively for the least efficient and the most efficient producers. These results showed that in general, soybean production in the commune of Tanguiéta was profitable despite the average level of technical efficiency of producers. Gross margins were all high, but the highest were among producers with the highest technical efficiency scores. This proved that there was a positive correlation between producers' profitability and their levels of technical efficiency. These results were close to those of (Chogou et al. 2018) in a study on the technical efficiency and economic profitability of soybean producers in Benin, where the gross margin per hectare varied between 45,550 FCFA and 224,430 FCFA respectively for poorly efficient producers and for the most technically efficient producers. Although the added value or gross margin was positive for all the producers in the sample, the most efficient producers (Group 2) had obtained a gross margin per hectare of 205,896 FCFA, i.e. almost 1.33 times that of producers in group 1 and 1.84 times that of producers in the entire sample surveyed. But, poorly efficient producers could improve their income 1.5 times if they managed to improve their level of technical efficiency to the threshold of the most technically efficient producers. Profits or even net margins varied in the same trends as those of gross margins. Consequently, the hierarchy obtained above for gross margins remained valid for profits at the level of the two groups of producers. The introduction of fixed charges in no way affected the financial profitability of the various groups formed with regard to the technical efficiency scores of the producers surveyed. From these different analyzes, and with regard to the benefit / cost ratio which was 0.93 and 1.18 respectively for the producers of group 1 and 2, it could be affirmed that the cultivation of soybeans was financially profitable in the municipality of Tanguiéta.

\section{Discussion}

\subsection{Technical Efficiency of Soybean Producers in the Commune of TanguiÉTa}

Soybean production is now an opportunity for Africa in general and for Benin in particular. However, the various studies on production systems highlight contrasting results on technical efficiency, deliverability, economic and financial profitability of farms in developing countries in general and Benin in particular (Bambani, 2020). In addition, the impoverishment of soils and the low level of income of farmers in the commune of Tanguiéta, despite their strong implications in cotton production, deserve to be reflected on other crops such as soybeans (Bambani, 2020). The central question in this study was to see whether a correlation exists between the level of technical efficiency and the profitability of soybean production. To assess the technical efficiency level of soybean producers in the commune, the stochastic Cobb Douglas-type production function was used to estimate the technical efficiency scores of producers. The results obtained reveal that the soybean producers in the municipality of Tanguiéta are generally inefficient with an average technical efficiency index of $45.62 \%$ (Bambani, 2020). This technical efficiency index is very low compared to the results obtained by other authors (Ichaou \& Balogoun, 2016) in Benin, on similar themes. Among the producers surveyed, only $7 \%$ obtained a technical efficiency index of between $70 \%$ and $91.1 \%$. These results indicate that most of the soybean producers surveyed have not yet achieved an acceptable average technical efficiency of at least $70 \%$. However, if errors and production techniques are mastered, with the combination of the same inputs, the average producer can increase his production by up to $49.92 \%$ if he manages to reach the level of the most technically efficient producer, i.e. 91, 1\% (Bambani, 2020).

According to (Dimon et al. 2020), agricultural activity is profitable in northern Benin. Paradoxically, poverty and food insecurity affect the populations of northern Benin in general and those of Pendjari in particular, notwithstanding the weight of agricultural activities in the area. For economists with an orthodox view of the 
causal relationship between agricultural deliverability and food insecurity in agricultural households, an increase in deliverability can, in theory, increase both producer income by controlling production costs without however securing the food of the populations (William \& Mahamoud, 2017). Consequently, the control of production calls for the technical efficiency of farmers if the desire remains that of efficient agriculture. However, the coefficient of the parameter $\sigma_{u}^{2}$ in the production function equation is significantly different from zero at the $5 \%$ level. As a result, part of the inefficiency of operators is due to technical errors. The parameter $\gamma$ which makes it possible to measure the contribution of the error due to technical inefficiency in the total variation of the outputs is $89 \%$. However, $11 \%$ of the differences between the observed production and the expected production of the producers are linked to random effects including measurement errors, which may be due to the nature of the data collected. Also, the scores of the estimated technical efficiency indices give an average of $45.62 \%$ for all the producers studied (Bambani, 2020). This average technical efficiency score is lower than that obtained by (Chogou et al. 2018 ) in a study on the technical efficiency of soybean producers in Benin, which is $61 \%$. These technical efficiency indices vary between $10.2 \%$ and $91.1 \%$. There is a considerable difference between the maximum score and the minimum score. The results obtained show that out of all the producers surveyed, less than an eighth, or $7 \%$ of respondents, have a level of technical efficiency greater than or equal to $70 \%$. The latter can be considered as head operators who can serve as a basis for advising other producers. However, this category of producers is very disabled in view of the distance from the districts in which the study was conducted. However, it is difficult to hope to have experience sharing between producers with a technical efficiency level of at least $70 \%$ with those with low technical efficiency levels in the study (Bambani, 2020).

Moreover, following the results of the estimation of the econometric model of the stochastic production function, the finding is that certain variables such as labor and area have a positive influence on efficiency, unlike the costs of seeds and of capital that negatively influence the technical efficiency of producers. As a result, the average technical efficiency level of $45.62 \%$ is significantly lower than those obtained by (Ichaou \& Balogoun, 2016; Chogou et al. 2018b). Indeed, (Ichaou \& Balogoun, 2016) estimated at 56\% the average level of technical efficiency of soybean producers in the town of Savè. As for (Chogou et al. 2018), the average technical efficiency level of soybean producers in Benin is $61 \%$. All of these authors deduce that soybean producers are technically inefficient. In view of these conclusions, soybean producers in the municipality of Tanguiéta are therefore technically inefficient.

\subsection{Agronomic Performance of Soybean Production}

To analyze the financial profitability of soybean producers according to their level of technical efficiency, agronomic performance indicators and the operating account of soybean producers are established. Subsequently, the statistical tests of comparison of Tukey's averages are carried out on the various indicators. Analysis of these different results confirms the positive link between financial profitability and the level of technical efficiency of soybean producers in the municipality of Tanguiéta. However, although soybean production is profitable, the results obtained remain very poor with regard to the soybean production potential in Benin, which is 2,500 $\mathrm{kg}$ to $3,000 \mathrm{~kg}$ per hectare (DSA-MAEP, 2020). Furthermore, these results allow us to understand that certain production factors such as the cost of capital and seeds negatively influence the output of producers. The gain in technical efficiency should allow soybean producers to better value the factors of production at their disposal, especially labor and the cost of seeds (Bambani, 2020).

With regard to the agronomic performance indicators of the soybean producers surveyed, the average area of the soybean production plots in the commune is $0.671 \mathrm{ha}$. This area remains small compared to the areas occupied by other crops such as cotton in the zone. The average annual soybean production obtained by producers is respectively $639,7 \mathrm{Kg}, 684.2 \mathrm{Kg}$ and $658,88 \mathrm{Kg}$ according to the different groups formed according to their levels of technical efficiency. The average production is $658.88 \mathrm{~kg}$ for all the producers surveyed. These results indicate that there is a significant difference between different groups of producers. Likewise, the average yield obtained is $959.2 \mathrm{~kg} ; 1204.8 \mathrm{Kg}$ and $1067.3 \mathrm{Kg}$ / ha respectively for groups (1 and 2) and for all respondents. These results show that there is a positive correlation between the level of technical efficiency of producers and the various indicators of agronomic performance. The most technically efficient producers (group 2) obtained an average yield of $1204.8 \mathrm{Kg}$ / ha by combining the factors of production (Bambani, 2020). This average yield is lower than that obtained by (Ichaou \& Balogoun, 2016) in the commune of Savè which is $1243.17 \mathrm{Kg} /$ ha and that obtained by (Chogou et al., 2018) which is $1410 \mathrm{Kg} /$ ha in Benign. This shows that producers in the municipality of Tanguiéta are still far from the soybean production potential in Benin, which is between 2,500-3,000 Kg / ha (Chogou et al. 2018). Also, the summary of the results from Tukey's statistical comparison test shows that variables such as average production, yield per hectare and gross product per hectare are respectively significant at the $5 \%$ thresholds for the first variable and $0 \%$ for the other two variables. In short, If the technical errors are corrected with the same 
resources, the average producer can increase his output up to $49.9 \%$ [1- (45.62 / 91.1)] if he manages to reach level d. technical efficiency of the most efficient producer.

\subsection{Financial Profitability of Soybean Production}

When we relate the total production cost of each group formed according to the level of technical efficiency of the producers to the average quantities produced, we obtain respectively $155.52 \mathrm{FCFA} / \mathrm{Kg}, 125.97 \mathrm{FCFA} / \mathrm{Kg}$ and 142.1 FCFA / Kg for groups ( 1 and 2) and for all producers surveyed. However, we note that the higher the level of technical efficiency, the lower the unit cost of production (Wilson \& Sima, 2007). This proves that there is a correlation between the level of technical efficiency and soybean production. The most technically efficient producers spent less over the production cycle. In addition, the average selling prices were 300 FCFA, 275 FCFA and 225 FCFA respectively for producers in groups (1 and 2) and for all producers. By comparing these prices with the unit costs of production, a margin on the unit cost of production of CFAF 144.48, CFAF 149.06 and CFAF 82.9 respectively for the different groups emerges. These average selling prices then covered production costs regardless of the group and the level of efficiency (Bambani, 2020).

The average gross margin at the end of the study is 154,520 FCFA for poorly efficient producers and 205,896 FCFA for the most efficient producers per hectare. The gross margin is the indicator generally used in most studies done in Africa in general and in Benin (Abdoulaye et al. 2017) in particular to measure the profitability of soybeanproducing farms. However, these results are similar to those obtained by (Chogou et al., 2018a) in Benin and to those obtained by (Ugbabe et al. 2017) in Nigeria and by (Hagos \& Bekele, 2018) in Ethiopia. These results are respectively 166,960 FCFA, 111,675 FCFA and 188,950 FCFA per hectare for these different authors. This confirms the results of the study that, soybeans are a profitable crop that can help improve the income of the producer, if the latter improves his level of technical efficiency. Also, from the analysis of the results of Table 4, the least technically efficient soybean producers should seek to reduce the cost of seeds and labor if they wish to reduce the cost of capital of their productions and increase their yields. At the same time, they must increase the areas sown. These results obtained allow us to deduce that certain production factors positively or negatively influence the profitability of producers. However, poorly efficient producers must take action to increase the factors that positively contribute to increasing the profitability of their production. This can no doubt increase their margins on variable production costs up to $49.9 \%$ as in the case of yield. In addition, from the analysis of the results of the Tukey means comparison test carried out on certain operating account variables, the variable load and overall load variables are significant at the $5 \%$ level. This test shows that these loads vary according to the groups of the different producers (Bambani, 2020). Even if the overall production costs obtained in the framework of the study are relatively lower than those obtained by (Chogou et al. 2018a). There is a difference between producers with regard to their overall production costs. The less efficient producers spent more to produce soybeans. However, the more inefficient the producers, the higher their production costs. In other words, the cost of production is negatively correlated with the level of technical efficiency of the producer. These results confirm the idea that producers must act on variable production costs in order to improve their profits. On the other hand, the average margin on variable cost and the average profit or average net margin are significantly variable at the $1 \%$ threshold. Indeed, the most technically efficient producers (group 2) achieved an average profit of 101,964 FCFA and the weakly efficient producers an average profit of 92,421 FCFA. Despite the commercial policy of producers in group 1 who stored and sold their productions at a higher price compared to producers in group 2, it is observed that the average profit of group 2 is higher than that of group 1 . However, weakly efficient producers have It is therefore in their interest to improve their levels of technical efficiency than to act on trade policies if they wish to increase the profitability of their productions. The benefit-to-cost ratios are 0.93 for the poorly efficient producers and 1.18 for the most efficient producers. These ratios show that soybean production is financially profitable depending on the level of technical efficiency of producers. If poorly efficient producers manage to correct their technical management errors, they can improve their financial profitability up to 1.5 times the current profit [ $92421 \mathrm{X}(1+(1-(45.62 / 91.1)=138128 \mathrm{FCFA}]$. This requires a good allocation of currently available resources. This study highlights the relationship between financial profitability and the level of technical efficiency of soybean producers in the municipality of Tanguiéta. These results are similar to those obtained by (Chogou et al. 2018b) where he compared the level of technical efficiency of soybean producers in Benin to their level of economic and financial profitability. However, it should be noted that unlike the results of this study, poorly efficient producers realized a loss in this study.

\section{Conclusion}

The results of this study shows that soybean production is profitable and has a positive correlation $(316,227 \mathrm{FCFA}>$ 262,890 FCFA) with low level of technical efficiency. The analysis of variance test and the Tukey mean comparison test confirmed this with a Fisher probability $(\mathrm{F}=0 \%)$. Given the high cost of seeds and labor in relation 
to the characteristics of the study area, any intervention that reduces the cost of these production factors contributes to increasing soybean profitability. The findings show that the average level of technical efficiency $(45.62 \%)$ is lower than that obtained from previous studies by other authors in Benin. given the advanced level of poverty of the populations and the continuous decline in the fertility of cultivable land in the study area, it is desirable that other experimental studies be carried out in order to analyze the factors of variability in agronomic performance and economical in a rotation or blending system of soybeans with other crops.

\section{Acknowledgements}

The authors are very grateful to all the financial participants (four Authors) who have contributed a lot to the data collection and colleagues who assisted in conducting the study and critiquing the manuscript. I confirmed that the all authors contributed equally to the study.

\section{References}

Abdoulaye, T., Ugbabe, O. O., Kamara, A., \& Mbaval, J. (2017). Profitability technical efficiency of soybean production in Nigeria p.13.

Aigner \& al. (1977). Approche de la Frontière Stochastique (p.15).

Ajavon, A. Y. C., Bello, S., \& Adegbola, P. Y. (2015). Incidences socio-économiques et environnementales de la culture du sésame dans la commune de Tanguiéta au Nord-Ouest du Bénin p.14.

Althouse, B. M., Eric, C. M. S. A. L. N., Leas, M., Mark, Dredze, ScM., Christopher, A., Longhurst, M. D. M.S., Davey, Smith, M. M. D. M. A. S., \& Ayers, J. W. M. A. (2019). The State of Soybean in Africa: Evaluating the Benefits of Implementing Soy-Maize Crop Rotations in Sub-Saharan Africa p.7.

Ambapour, S. (2001). Estimation des frontières de production et mesures de l'efficacité technique p.27.

Atchadé, Y., Keshavarz, H., \& Michailidis, G. (2018). Analyse des Variances et Régression sur variables catégorielles. p.46.

Bambani, C. R. (2020). Efficacité technico-financière des producteurs du soja dans la pendjari: cas de la commune de Tanguiéta. Mémoire de Master Recherche, Ecole Doctorale des Sciences Agronomiques et de l'Eau, Université de Parakou, Bénin. 67 p.

Biaou \& Saliou. (2018). Efficacité technique et rentabilité financière de la production de semences de riz : cas du périmètre irrigué de Koussin-lélé dans la commune de Covè au bénin. (P.16).

Charnes et Coll. (1978). Approche de l'Analyse de l'Enveloppe des Données. (p.12).

Chogou, S. K., Kpadé, C. P., Santos, F., \& Mensah, G. A. (2018b). Efficacité technique et rentabilité économique de la production du soja au Bénin. p.13.

Chogou, S. K., Okry, F., Santos, F., \& Hounhouigan, D. J. (2018a). Efficacité technique des producteurs de soja du Bénin. p.18.

Chombart de Lauwe, J., Poitevin, J., \& Tirel, J. C. (1966). Nouvelle gestion des exploitations agricoles. p.7.

Dao, D., Silue, N. Z., Valerie Kouame, H. K., \& Koné, M. (2019). Analyse de la rentabilité économique des systèmes de production à base d'igname: cas des sites de Leo et Midebdo au Burkina Faso. p.10.

Debruyne, L., Broman T., Bergström, S., Olsen, B., On, S. L. W., \& Vandamme P. (2010). Campylobacter subantarcticus sp. nov., isolated from birds in the sub-Antarctic region. Int J Syst Evol Microbiol, 60, 815819. https://doi.org/10.1099/ijs.0.011056-0

Dimon, E. Y., Yabi, A. J., Biaou, G., Floquet, A., \& Degla, P. (2020). Productivité agricole et sécurité alimentaire des ménages agricoles du Département de l'Atacora au Bénin. p.11.

DSA-MAEP (Direction des Statistiques Agricoles- Ministère de l'Agriculture, de l'Elevage et de la Pêche). (2020). Indicateurs macroéconomiques sur le secteur agricole au Benin. p.4.

Edalo, V., Yaoitcha, A. S., Houehanou, T. D., Muhashy Habiyaremye, F., de Bisthoven, L. J., Assogbadjo, A. E., Houinato, M. R. B., \& Sinsin, B. A. (2019). Perceptions locales de l'impact des feux de végétation sur les services écosystémiques d'approvisionnement autour de la Réserve de Biosphère de la Pendjari au nord du Bénin. p.21.

Farrell, M. J. (1957). The Measurement of Productive Efficiency. Journal of the Royal Statistical Society. Series A (General), (p. 253-290). https://doi.org/10.2307/2343100

Ghali, M., Daniel, K., Colson, F., \& Latrufe, L. (2013). Diagnostic de l'efficacité technique des exploitations 
agricoles françaises : Une analyse de l'efficacité d'utilisation des ressources énergétiques et exploration des déterminants relevant des pratiques agricoles. p.29.

Hagos, B. (2018). Cost and returns of soybean production in Assosa Zone of Benishangul Gumuz Region of Ethiopia. p.7.

Ichaou, B. (2016). Estimation of stochastic frontier of the technical efficiency of the soybeans production's determinants in Benin : The case of the commune of Savé. p.11.

INSAE (Institut National de la Statistique et de l'Analyse Economique). (2013). Dynamique de la population. Quatrième Recensement Général de la Population et de l'Habitation, Février, 2013, Cotonou, Bénin.

INSEE (Institut National de la Statistique et des Etudes Economique). (2016). Statistiques, définitions, méthodes et qualité. Définitions mises à jour. p.2.

Kocisova, K. (2015). Application of the DEA on the measurement of efficiency in the EU countries. (p.12).

Kombienou, P. D., Sabaï, K., Diogo, R. V. C., Dagbenonbakin, G. D., \& Mensah, G. A. (2020). Incidences SocioEnvironnementales et Economiques des Activités Agricoles Dans Le Nord-Ouest De L'Atacora Au Benin. REV. RAMRES - VOL.08 NUM.01. 2020** ISSN 2424-7235. Science de la vie, de la terre et agronomie.pp.37-47.

Koopmans, T. C. (1951). An Analysis of Production, an technical efficiency: A survey of empirical applications in agricultural economics. Agri. Econom., 7, 185-208. Central Bank of Nigeria, 1999. Annual Report and statement of Accounts. CBN Publications. https://doi.org/10.1016/0169-5150(92)90049-5

MAEP (Ministère de l'Agriculture, de l'Elevage et de la Pêche). (2019). Rapport de performance du secteur agricole p. 104.

Oloumilade, J., Marcellin, O., \& Yabi, A. (2019). Facteurs explicatifs de l'adoption des varietés améliorées de soja dans le département du Borgou au Nord du Bénin. p.26. https://doi.org/10.19044/esj.2019.v15n28p148

Penot, E. (2008). Harmonisation des calculs économiques et correspondance avec le logiciel Olympe pour la modélisation économique des exploitations agricoles p. 31 .

Schneider, A., Huyghe, C., \& Coord (2015). Les légumineuses pour des systèmes agricoles et alimentaires durables. p.515. https://doi.org/10.35690/978-2-7592-2335-0

Scordia, C., Zahm, F., Ugaglia, A. A., De l'homme, B., Gafsi, M., Girard, S., \& Scordia (2020). Evaluation de la performance économique globale des exploitations agricoles : Cadre conceptuel et applications. p.32.

Ugbabe, O. O., Aboulaye, T., Kamara, A. Y., Mbavai, J., \& Oyinbo, O. (2017). Profitability and Technical Efficiency of Soybean Production in Northern Nigeria. Tropicultura, pp.203-214.

William, R., \& Mahamoud, B. (2017). Global alliance for improing food security. p.237.

Wilson, P. W., \& Simar, L. (2007). Efficacité technique et allocative des firmes industrielles. p.7.

Yabi, J. A., Paraïso, A., Yegbemey, R. N., \& Chanou, P. (2012). Rentabilité Economique des Systèmes Rizicoles de la Commune de Malanville au Nord-Est du Bénin. p.12.

\section{Copyrights}

Copyright for this article is retained by the author(s), with first publication rights granted to the journal.

This is an open-access article distributed under the terms and conditions of the Creative Commons Attribution license (http://creativecommons.org/licenses/by/4.0/). 